\title{
A MODEST REPLICATION TO A LENGTHY DISCOURSE *
}

\section{Morris S. ARNold}

Having had before me for some time the frightening example made of Richard Mylward, I shall keep my replication (as the old lawyers would have called it) extremely brief. The story goes that the hapless Mylward so angered Ellesmere by drafting a replication of 120 pages that he was arrested, brought into Westminster Hall, and paraded before the courts with his head stuck through his draft and the papers hanging " 'about his shoulders, with the written side outward." 1 The tale is useful not only as an inducement to brevity, but also as a reminder of the extraordinarily implacable and disagreeable personality of the man upon whose alleged views the reader has just been asked to place principal reliance. ${ }^{2}$

Contrary to the clear implication of Mr. Campbell's part of the Discussion piece, I nowhere indicated that a special regard for trial by jury was the sole reason for opposition to equity courts in colonial America. Indeed, I very carefully acknowledged that there were other reasons for that opposition, and contended simply that affection for jury trials was one significant source. ${ }^{3}$ Nor did I assert that most American jurisdictions never had separate equity courts. In fact, I specifically admitted that many jurisdictions did, but noted that in a good many of them trial by jury was a regular feature. ${ }^{4}$ Since I wrote the original piece, further research has

- See Campbell \& Le Poidevin, Complex Cases and Jury Trials: A Reply to Professor Arnold, 128 U. PA. L. Rev. 965 (1980).

I have modeled the title for my response on David Dudley Field's pithy rejoinder to his critics, which Professor Stephen B. Burbank kindly brought to my attention. See D. Field, A Short Response to A Long Discourse (1884).

1 The story is a very familiar one. A brief account can be found in 5 W. Holdsworth, A Historx OF ENGLISH LAW 233 \& n.7 (3d ed. 1945) (quoting Mylward v. Weldon (Ch. 1596), in C. Monro, Acta Cancellariae 692, 693 (London 1847)).

2 See Campbell \& Le Poidevin, Complex Cases and Jury Trials: A Reply to Professor Amold, 128 U. PA. L. Rev. 965 (1980).

3 Arnold, A Historical Inquiry into the Right to Trial by Jury in Complex Civil Litigation, 128 U. PA. L. Rev. 829, 832 (1980).

4 Arnold, supra note 3, at 835-38. Mr. Campbell states that juries were used in England in the course of equity suits. Campbell \& Le Poidevin, supra note 2, at 968 n.14. That is true, and far from denying it, I stated that that was the case. Amold, supra note 3 , at 836-37. But I maintain that the use of juries was more extensive in this country and that jury verdicts were in many places considered binding. By contrast, in English equity practice references of facts to juries "were for the convenience and at the discretion of the Chancellor," and jury verdicts were not binding on him. Langbein, Fact Finding in the English Court of Chancery: A Rebuttal, 83 YALE L.J. 1620, 1624 (1974). 
disclosed that colonial Delaware also had a statute requiring a jury trial of all matters of fact arising in its equity courts. ${ }^{5}$ Obviously, my point in focusing on these practices was not that the Constitution requires equitable suits to be tried by jury today; the seventh amendment applies to suits at common law. The fact the framers did not require juries in equity is thus completely irrelevant to my point. $^{6}$ Rather, these practices are significant because they establish even more firmly that eighteenth-century Americans had a special attachment to the jury.

It does not seem to me to be very radical to suggest that, in deciding the scope and correct meaning of the seventh amendment, this high regard for trial by jury be given great weight. In particular, I believe this reverence for jury trial indicates that colonial Americans were not so distrustful of juries as to allow equity to take jurisdiction from law on the ground of a so-called "complexity." Indeed, this attitude explains why those who take the side against me are unable to cite a single American case demonstrating such an equitable power.

Mr. Le Poidevin chides me for ignoring certain relevant eighteenth-century cases and concentrating my efforts on two more ancient ones. I did that because the other cases are all actions of account and, as I indicated, I believe that their appearance in equity in the first place was due to the superior process available there. Moreover, what made the old action of account cumbersome had nothing to do with the practical limitations of jurors but rather with the inconvenience of putting a large number of questions to them. These precedents simply do not reveal a generalized equitable jurisdiction over "complex" cases.

Mr. Le Poidevin offers an alternative analysis of Towneley $v$. Clench, and prefers to see the decision there as turning on a difficulty involving the Statute of Uses and the Statute of Wills. His

I stand by all the statements in my Article regarding the nature and extent of equitable jurisdiction in eighteenth-century Massachusetts and Pennsylvania, and invite the reader to examine the authorities which Mr. Campbell cites in opposition to my account. See Campbell \& Le Poidevin, supra note 2, at 967-70.

5 An Act for the establishing Courts of Law and Equity within this Government, in Laws of the Government of New-Castue, Kent and Sussex Ufon Detawware 39, 48 (Philadelphia 1741), reprinted in The Earlitest Prunted Laws of DELAwARE 1704-1741, at 47, 56 (1978).

$6 \mathrm{Mr}$. Campbell wonders why I made no reference to the debates surrounding the adoption of the seventh amendment. The reason is that those debates are inconclusive and reveal at the very most some lack of enthusiasm for constitutionally compelling jury trial in equity causes. If there had been any real aversion to employing juries in equity one would think that their use there would have been forbidden. But it cannot be successfully contended that the seventh amendment prohibits such a procedure. 
analysis ignores the fact that the judgment in the case wholly omits any reference to this alleged difficulty. It is true, as Mr. Le Poidevin notes, that there was no requirement that judgments set forth their reasons. But the judgment in Clench in fact advances reasons in support of the decree, and those reasons do not at all relate to the supposed complexity of the case. The judgment proceeds instead on the assumption that the defendant was still withholding the plaintiff's evidence, thus disabling him from vindicating his rights at law. As Mr. Le Poidevin admits, no legal action was available to the plaintiff for recovering his deeds. Does it not seem clear that this was the basis for enjoining the defendant's legal action? But much more fundamentally, even if Ellesmere made the statement attributed to him, and even if Mr. Le Poidevin's analysis correctly explains it, the case remains unique and without either precedent or progeny. It never was a basis for denying a jury to a plaintiff that complicated matters of law might arise in the course of a trial. ${ }^{7}$

Finally, Mr. Le Poidevin seems to think that my entire argument is somehow exploded if equity had concurrent jurisdiction over complex cases. ${ }^{8}$ That is not true, for the plaintiff is the master of his cause of action; once it is characterized as legal by him, the ordinary attributes of a trial of law, including the availability of a jury, necessarily follow. ${ }^{9}$

$7 \mathrm{Mr}$. Le Poidevin insists I have admitted that in Blad v. Bamfield, a jury was stopped from hearing a case because it was "complex." Campbell \& Le Poidevin, supra note 2 , at 974 n.48. I make no such admission, as the reader is invited to discover for himself.

${ }^{8}$ See Campbell \& Le Poidevin, supra note 2, at 974 n.45.

9 See generally F. James \& G. HAZARd, Crvm Procedure 370-73 (2d ed. 1977); 1 J. Pomerox, A Treatise on Equity Jurusprudence $\$ 179$, at 251-52 (5th ed. 1941); James, Right to a Jury Trial in Civil Actions, 72 YALE L.J. 655, 671-73 (1963). 